\title{
Impact of MSME Assistance Program by East Java Province to Resolve the Economic Impacts of Covid-19
}

\author{
Agus Adriyanto ${ }^{1}$, Maryanti ${ }^{2}$, Kukuh Setyo Pambudi ${ }^{3}$ \\ ${ }^{123}$ Faculty of National Security, Indonesia Defense University \\ Correspondent: a adriyanto@yahoo.com ${ }^{1}$
}

$\begin{array}{ll}\text { Received } & \text { : August 08, } 2021 \\ \text { Accepted } & \text { : August 25, } 2021 \\ \text { Published } & \text { : October 31, } 2021\end{array}$

Citation: Adriyanto, A., Maryanti., Pambudi, K.S.(2021). Impact of MSME Assistance Program by East Java Province to Resolve the Economic Impacts of Covid-19. Ilomata International Journal of Social Science, 2(4), 296-307.

https://doi.org/10.52728/ijss.v2i4.376

\begin{abstract}
This paper aims to provide a perspective on assistance to MSMEs in East Java in the face of the Covid19 pandemic. So far, MSMEs have been proven to be one of the economic drivers that accommodate the majority of workers in Indonesia. The existence of the Covid-19 Pandemic has depressed MSMEs throughout Indonesia and often have to go out of business. It seems that the government assistance that has been provided in the context of Covid-19 is still focused on individual or family assistance. Therefore, the authors consider MSMEs to be an essential factor in efforts to overcome the impact of Covid19, especially in East Java. This paper uses the review literature as a method of data collection and research. The research results are expected to be an input for the Government, especially East Java Province, to consider the existence of capital assistance for MSME's.
\end{abstract}

Keywords: MSME, Capital Assistance, Covid-19, East Java Province

\section{INTRODUCTION}

The COVID-19 pandemic that attacks life globally has caused uncertainty in people's lives in the world. Since the announcement of the positive case of COVID-19 in Indonesia on March 2, 2020, various efforts have been made by the government, starting from physical distancing, activities at home, closing crowd centers, to reducing the density of workers in the industrial

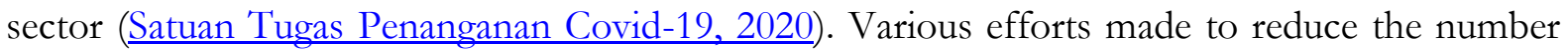
of transmissions such as limiting oneself from crowds have an impact on community social relations. But in reality, as of this writing, the spread of COVID-19 is still high, both globally and in Indonesia (Rahmah, 2020; Utomo \& Hanggraeni, 2021).

President Joko Widodo at the Extraordinary G20 Summit last March invited the leaders of the G20 countries to jointly face the global COVID-19 pandemic and the weakening world economy. In the same month, President Joko Widodo announced that in a public health emergency, facing the COVID-19 outbreak by choosing Large-Scale Social Restrictions in accordance with Law Number 6 of 2018 concerning Health Quarantine. In this Government Regulation (PP) Number 21 of 2020, what is meant by Large-Scale Social Restrictions are restrictions on certain activities of residents in an area suspected of being infected with Corona Virus Disease 2019 (COVID-19) in such a way as to prevent the possible spread of Corona 
Impact of MSME Assistance Program by East Java Province to Resolve the Economic Impacts of Covid-19

Adriyanto, Maryanti, Pambudi

Virus Disease 2019 ( COVID-19). Article 4 Paragraph (1) PP Number 21 of 2020 states that Large-Scale Social Restrictions at least include:

a. school and workplace holidays;

b. restrictions on religious activities; and/or

c. restrictions on activities in the workplace or public facilities.

There are at least two visible effects of the pandemic on the economy. First, from the health aspect, the infected workers become less or even unproductive. The second is the economic impact of efforts to close the public and private sectors including schools and production centers, travel bans and population quarantines. From an economic perspective, various closures and travel bans taken to reduce the spread have the other side of reducing productivity and lowering the number of workers because their workplaces are also economically affected (Susanti \& Widajatun, 2021; Yousef, 2020).

Although remote work can be done by taking advantage of the development of digital technology, not all tasks can be done remotely. Human presence in the location or workplace is needed, especially in the economic sector that handles tangible goods. Various other health measures aimed at slowing the spread such as temporarily closing schools can reduce employment and indirectly for workers who have to stay at home to focus on children's distance learning. The shock effect of the pandemic on the economy could be more direct and permanent reducing employment by reducing the workforce in all areas of business (Shafi et al., 2020).

Based on the latest data taken from the website of the COVID-19 Task Force, as of Sunday $(27 / 9 / 2020)$, the number of confirmed cases in Indonesia was 275,213 , recovered as many as 203,014 and died as many as 10,386 (Satuan Tugas Penanganan Covid-19, 2020). Quoted from the East Java Provincial Government website regarding COVID-19, East Java Province has 42,890 cases, with 3,827 active, 35,945 recovered and 3,118 dead (Pemprov Jawa Timur, 2020)

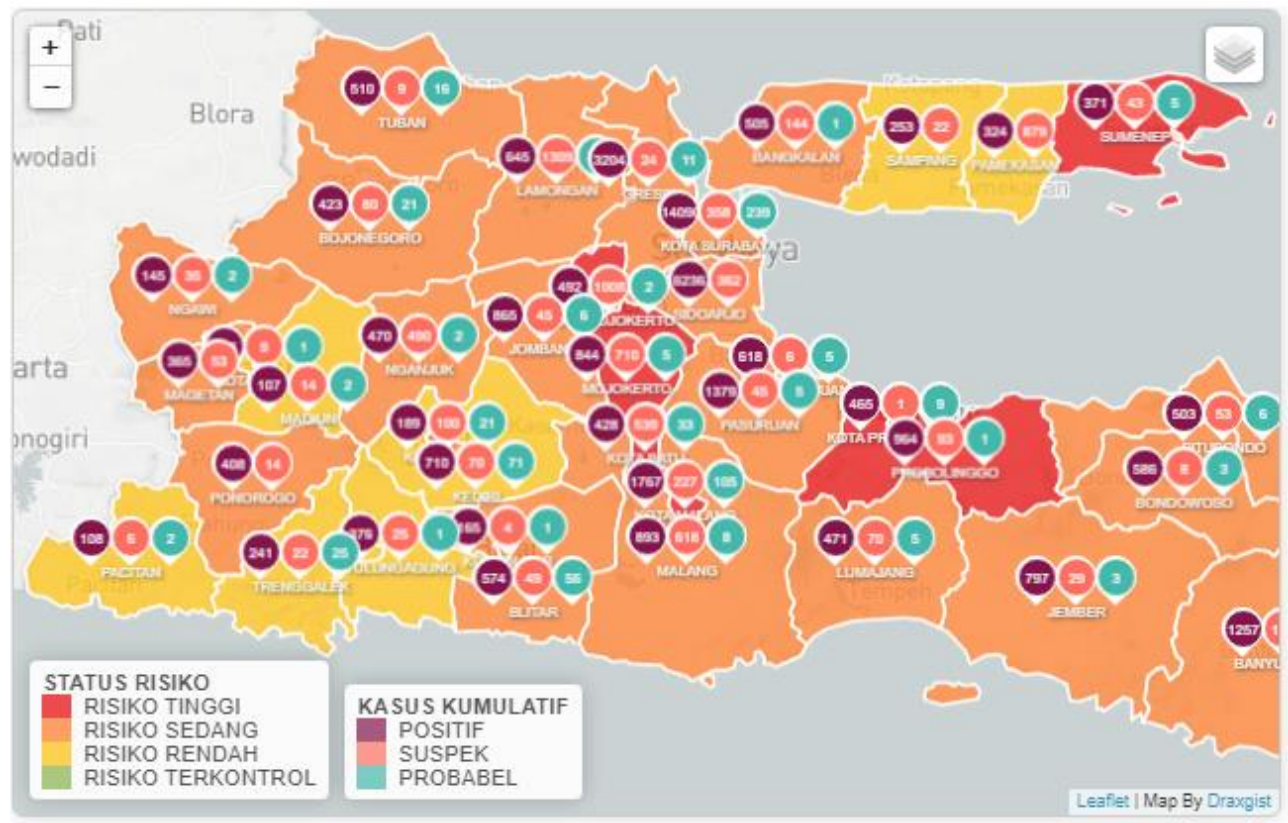

Figure 1. Peta Sebaran COVID-19 Jatim (Source: (Pemprov Jawa Timur, 2020))

East Java is one of the network hubs that connects economic transactions from various provinces in Indonesia. This province is also one of the provinces most affected by the Covid-19 pandemic, 
Impact of MSME Assistance Program by East Java Province to Resolve the Economic Impacts of Covid-19

Adriyanto, Maryanti, Pambudi

estimated 3.8 million workers in all socio-economically affected districts/cities have the potential to lose their jobs (Arfani \& Nashrullah, 2020). The Deputy Governor of East Java, Emil Elestianto Dardak, on Monday (30/3/2020) said that the affected workers came from various sectors such as trade, processing, transportation, accommodation, food and beverages (Pemprov Jawa Timur, 2020). Almost all micro, small and medium enterprises (MSMEs) rely on incoming income to carry out economic activities. With the shock effect of Covid-19 causing a sudden cessation of income, MSMEs are very vulnerable to going bankrupt (BPS Jawa Timur, 2020).

On the other hand, according to data from the Central Statistics Agency (BPS) of East Java Province in March 2020, the number of poor people in East Java reached 4,419.10 thousand people (11.09 percent), an increase of 363.1 thousand people compared to the current condition. September 2019 which amounted to 4,056.00 thousand people (10.20 percent). In measuring the poverty rate, BPS uses the concept of the ability to meet basic needs (basic needs approach). In this case, poverty is seen as an economic inability to meet basic food and non-food needs as measured from the expenditure side (BPS Jawa Timur, 2020). One of the factors that are considered to be the trigger for the increase in the poverty rate is the COVID-19 pandemic which has caused a reduction in community activities (Sekiraqa et al., 2021).

\section{METHOD}

Literature review or literature study is used by the author in compiling this paper. Literature study is a method used in compiling a scientific manuscript by collecting previously available literature and data. The data and literature are then used in answering the research questions posed or in order to strengthen the arguments put forward. Literature study is one of the methods in research that can provide a fairly complete perspective in assessing a research object (Rowley \& Slack, 2004).

The implementation of the literature study begins with determining the object of research and research questions that are answered using previous research. Several relevant studies will be the main reference in formulating research conclusions (Booth et al, 2021). In relation to the research conducted, the object of research in this study is the assistance of MSMEs in anticipating the impact of Covid-19 in East Java. Several studies used in this study were sourced from cross-disciplinary studies. So it is hoped that it will produce quite comprehensive suggestions in formulating policies that will be suggested later. The following is the framework of thought proposed in this paper.

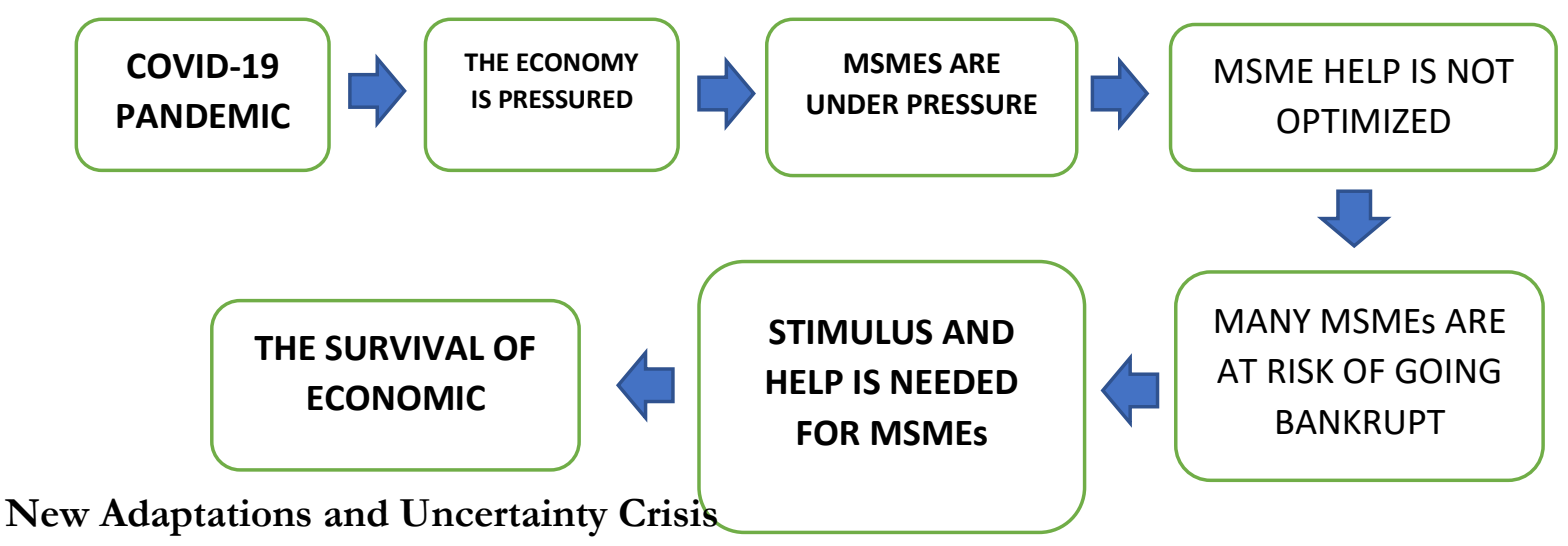




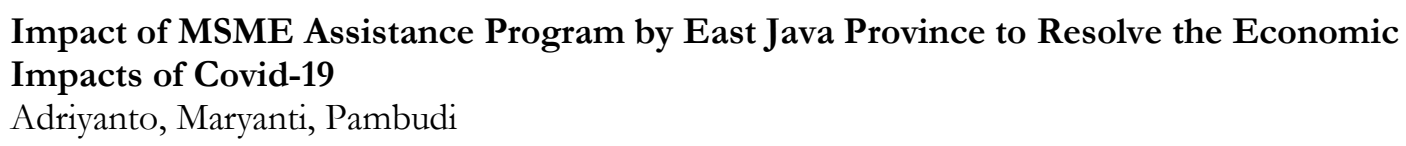

The central government has begun to promote new adaptation policies starting from the office and industrial sectors so that the economy continues to run. Previously, the government had issued a plan if residents under 45 years of age could work in offices during the COVID-19 pandemic (Mansoor, 2021). This policy received various challenges from the community because it saw the transmission rate of COVID-19 was still relatively high in Indonesia. If this policy is really implemented, the government must really follow the requirements given by the world health authority, WHO, to start a new normal. In addition, the government and related parties need to ensure compliance with the health protocols implemented (Sreeramula \& Rahardjo, 2021).

The Government of Indonesia has announced plans to implement this new adaptation in consideration of epidemiological studies and regional preparedness. This new government action can be analyzed using the AGIL or Adaptation, Goal Attainment, Integration, and Latency scheme as follows (Alhaq, 2020):

1. Adaptation, which means that the new normal policy encourages people to adapt while still implementing health protocols.

2. Goal attainment relates to the need for mutual consensus between the community and the government in overcoming the impact of COVID-19.

3. Integration as a system that is interconnected with one another or adapted to adaptation, goal achievement and pattern maintenance.

4. Pattern maintenance (latency) is related to effective patterns in overcoming the COVID-19 pandemic.

The problem that occurs in Indonesia is the lack of a single policy for handling COVID-19, both between the center and the regions as well as between institutions/ministries. Compared to policies that tend to be fragmented, comprehensive policies are needed to address socioeconomic impacts to community preparedness in the future. If leaders are unable to demonstrate leadership and capacity regarding crisis situations and their handling, it will result in public distrust of the resulting policies (Ashraf, 2020; Cahyadini et al., 2021).

With the Indonesian government system that adheres to decentralization, the handling of COVID-19 is influenced by how each region responds to the pandemic. In this case the implementation of national reference materials and recommendations will depend on local government, community support and available funding. For regions that do not have adequate resources, they are not only facing health problems but also guaranteeing the economic needs of the community. In several cases that occurred in several areas in East Java, this was exacerbated by the lack of social solidarity between people and people's obedience to local authorities. 
Impact of MSME Assistance Program by East Java Province to Resolve the Economic Impacts of Covid-19

Adriyanto, Maryanti, Pambudi

The COVID-19 pandemic has created uncertainty that affects people's level of concern and mental health. Based on the BPS COVID-19 Impact Social Demographic Survey, the majority of respondents (65.03 percent) were worried or very worried about the conditions and news regarding COVID-19 and 69.43 percent of the people were also worried or very worried when they had to do activities outside the home. In this case, anticipatory steps are needed against the impact of a very large pandemic and can accumulate into a double pandemic or the problems that accompany it. Therefore, special attention is needed on the psychological impact such as mental health for better socio-economic recovery (Badan Pusat Statistik, 2020).

\section{Social Resilience of the East Java Community Against Covid-19}

After the implementation of the national Work From Home (WFH) policy, there was an increase in community activities at home. With the spread of the virus from person to person, people are starting to get used to avoiding gathering activities but are still required to be productive. Based on the Big Data Review on the Impact of COVID-19, activity at work has decreased by an average of $16.5 \%$ per day and is inversely proportional to the increase in activity at home by 9.5\%. The COVID-19 pandemic has led to an increase in the trend of increasing buying and selling in e-commerce. The BPS survey results show that as many as 31 percent of respondents experienced an increase in online shopping activity, 28 percent of respondents experienced a decrease and the rest remained (Badan Pusat Statistik, 2020).

The resilience of the community itself can arise as a result of social solidarity actions so as to strengthen social capital. This social capital has elements that are able to encourage the emergence of innovative and productive behavior which can be seen from the diversity of forms of solidarity action (Kustiningsih \& Nurhadi, 2020). In general, solidarity actions are aimed at vulnerable groups who are considered more in need, such as the poor, groups who have lost their livelihoods due to COVID-19, informal workers, groups with limited access to health facilities, LGBT groups and so on. One type of social solidarity action in response to COVID-19 is empowerment that is more long-term in nature (Windarwati et al., 2020).

Social resilience is the ability of the community to use existing resources so that they can survive in crisis conditions. The COVID-19 pandemic forces people to defend themselves by adapting quickly to the current situation and conditions. Technological developments have driven the transformation from traditional society to digital society. MSME business groups and the household sector can take advantage of these technological developments. Therefore, a technological literacy approach that is more directly touching the grassroots of the community is needed (Bai et al., 2021; Wanasida et al., 2021). 
Impact of MSME Assistance Program by East Java Province to Resolve the Economic Impacts of Covid-19

Adriyanto, Maryanti, Pambudi

\section{Social Assistance and Economic Resilience in Lower Communities}

The impact of COVID-19 continues to be felt around the world, disrupting the social fabric of people's lives, running businesses and daily behavior, and triggering a huge shock effect on the economy. In many countries, there are various responses taken by the government to deal with COVID-19 and its impacts. Several developed and developing countries have experienced balance sheet levels with respect to Gross Domestic Product (GDP) and have proposed strong economic and social stimulus packages to protect economies and populations from the major impacts of the pandemic (Allam, 2020). On the other hand, less developed countries still rely mostly on foreign financial aid and emergency bailout packages to protect their economies and populations (Tosepu et al., 2020).

The Indonesian government has designated the COVID-19 pandemic as a non-natural national disaster that threatens all Indonesian people. As a form of state responsibility to the community, the government from the center to the regions provides social assistance (Bansos) to the community, especially those affected and targeted by the poor. There are various forms of social assistance provided by the government, such as BLT (Direct Cash Assistance), Basic Food Assistance, Electricity Subsidies, Beneficiaries of the Family Hope Program, Pre-Employment Card incentives, and Smart Indonesia. The problem with distributing social assistance that was reported to the Ombudsman of the Republic of Indonesia was the uneven distribution of aid, both in terms of time, target/recipient community and distribution area; unclear procedures and requirements for receiving assistance; people whose conditions are more urgently hungry are not registered and vice versa, there are those who are registered but do not receive assistance; and some are unable to receive assistance at their place of residence because of the migrants' ID cards (Dewi, 2020).

In East Java, some of the 3.8 million workers affected by the socioeconomic impact of COVID19 have been protected by Non-Cash Food Assistance (BPNT). Quoted from Antara, East Java Governor Khofifah Indar Parawansa in March said that the East Java Provincial Government still needed greater additional funds so that it could carry out social programs related to labor intensive and affected MSME actors (Dewi, 2020). The Assistant to the Indonesian Ombudsman, provided three recommendations related to social assistance issues, namely:

1. Synchronization of Central and Regional data via E-KTP on civil registration.

2. The local government records manually through the sub-district and village/lurah as confirmation of the affected residents.

3. Asking residents to report to the lurah/village to register themselves as recipients of social assistance. 
Impact of MSME Assistance Program by East Java Province to Resolve the Economic Impacts of Covid-19

Adriyanto, Maryanti, Pambudi

\section{RESULT AND DISCUSSION}

President Jokowi stated that the COVID-19 pandemic had caused world economic growth to contract sharply. In the second quarter of 2020, several countries experiencing slowing economic growth include India minus 23.9 percent, the UK minus 27.1 percent, Malaysia 17.1 percent, Singapore 13.2 percent and Indonesia minus 5.32 percent (Aldila, 2020). Many business actors in Indonesia have temporarily or permanently closed their businesses as a result of the COVID-19 transmission. The results of the Social Demographic Survey of the Impact of COVID-19 BPS on 87,379 respondents showed that $2.52 \%$ of survey respondents had recently experienced layoffs due to the closing of the company/business place where they worked.

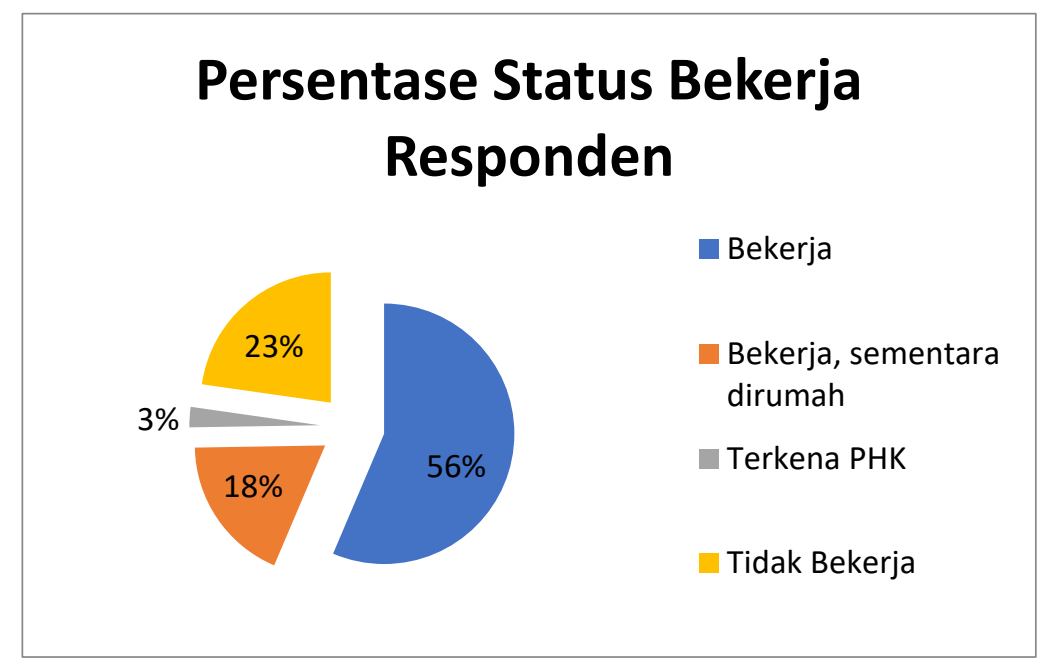

Source: Social Demographic Survey of the Impact of COVID-19 (Badan Pusat Statistik, 2020)

Although the impact of COVID-19 was felt by all business sectors, several business sectors experienced a significant decline in production due to a decline in production sales. This decline then affects income as a result of being affected by the pandemic.

Both people who work or are temporarily housed have experienced a decrease in income. However, the percentage of respondents who experienced a decrease in income while being temporarily laid off was higher than those who were still working. The income groups of the poor, vulnerable to poverty and those working in the informal sector are the groups most affected by the Covid-19 pandemic. The survey shows that 70.53 percent of respondents in the low-income group (less than 1.8 million) admit to experiencing a decrease in income (BPS, 2020). In addition, specifically for the East Java region, 5,348 workers from 210 companies were laid off (PHK) and 32,365 from 555 employee companies were laid off (CNN Indonesia, 2020). In the economic sector, business actors are trying to make production cost efficiency, which is usually done by reducing the number of employees to cutting employee salaries. With the 


\section{Impact of MSME Assistance Program by East Java Province to Resolve the Economic Impacts of Covid-19 \\ Adriyanto, Maryanti, Pambudi}

sluggish economy, MSMEs become business actors who have the potential to go out of business. On the other hand, the decline in income experienced by the community also affects the household sector carrying out economic activities. Meanwhile, people who are under poverty become an increasingly marginalized group because their vulnerabilities cannot meet their basic needs (Arfani \& Nashrullah, 2020).

Explanation of Law No. 20 of 2008 concerning Micro, Small and Medium Enterprises states that Micro, Small and Medium Enterprises (MSMEs) are business activities that are able to expand employment opportunities and provide broad economic services to the community, and can play a role in the process of equity and increase community income. encourage economic growth, and play a role in realizing national stability. The MSME business world is the business world that has been significantly affected by the COVID-19 pandemic, considering that MSMEs contribute 60.3 percent of Indonesia's total gross domestic product (GDP). MSMEs have absorbed 97 percent of the total workforce and 99 percent of total employment (Jayani, 2020). At the beginning of the spread of COVID-19 in Indonesia, the government provided industrial support of Rp. 70.1 trillion and the business world of Rp. 150 trillion.

\section{MSME Assistance}

Secretary of the Ministry of Cooperatives and SMEs Rully Indrawan said that several MSME actors had started to rise with assistance from the government through the National Economic Recovery (PEN) scheme such as KUR relaxation, interest subsidies, working capital, as well as Productive Presidential Assistance (Banpres) for micro businesses in the form of grants (Santia, 2020). With the increasing development of e-commerce, the Ministry of Cooperatives and SMEs continues to encourage and accelerate MSMEs to go digital through training and mentoring programs. This is because only 13 percent or 8 million of the 64 million MSMEs in Indonesia are present on digital platforms (Jayani, 2020).

Although several efforts from the central government have been carried out, the slowing economic development and even the imminent economic recession has made MSMEs again at a vulnerable point. Even in a survey conducted by LIPI it is known that $94.69 \%$ of businesses experienced a decline in sales. Furthermore, as many as $47.13 \%$ of businesses were only able to survive until August 2020,72.02\% of businesses will close after November 2020, and $85.42 \%$ of businesses can survive the longest within one year since the pandemic. This condition is clearly very concerning considering that MSMEs currently number approximately 64 million (Santia, $\underline{2020})$.

If you look at the contribution contributed by MSMEs, in general MSMEs in Indonesia have a contribution of $60.3 \%$ of the total gross domestic product (GDP). In addition, MSMEs absorb 


\section{Impact of MSME Assistance Program by East Java Province to Resolve the Economic Impacts of Covid-19 \\ Adriyanto, Maryanti, Pambudi}

$97 \%$ of the total workforce and $99 \%$ of the total employment (Badan Pusat Statistik, 2019). The very large contribution of MSMEs makes MSMEs must receive special attention. So far, the government has launched many programs as a stimulus for MSMEs. One of the programs launched by the central government is productive assistance which provides money worth 2.4 million Rupiah for 12 million MSMEs (Ihsanuddin, 2020). Although this is a step forward, researchers see that this assistance is still lacking and deserves to be developed. Considering that the existing MSMEs are in a vulnerable condition of around 70 percent, so the amount given is of course still very far from what is needed .

Based on some of the conditions above, the authors argue that the East Java Provincial Government can take steps to assist the central government in helping the affected MSMEs. Based on data from the Department of Cooperatives and SMEs of East Java Province, there are 13,663,614 SMEs spread across all regencies and cities (Pemprov Jawa Timur, 2020). So based on these data, the number of East Java MSMEs is among the largest in Indonesia. Like other MSMEs in Indonesia, MSMEs in East Java must also be under pressure and need assistance from the Government. Therefore, the provincial government in its capacity can provide productive assistance for MSMEs that are not touched by the central government. Thus, economic resilience in East Java will be stronger and able to survive the Covid-19 pandemic.

\section{CONCLUSION}

The Covid-19 pandemic has brought a very significant blow to Indonesia. Indonesia, which for 20 years has never experienced a contraction, is even now predicted to be approaching a recession phase. Therefore, at this time the government, both central and regional, is very aggressive in providing stimulus to reduce the impact of Covid-19 on the entire community. However, even though there has been quite a lot of social assistance provided to the community and MSMEs in the context of dealing with Covid-19, this policy is still considered insufficient because it will not be able to maintain MSMEs as a bulwark of the national economy. even when the central government announced assistance to 12 million MSMEs, the number affected was still more than the affordability of aid. This refers to data where as many as $85.4 \%$ of MSMEs cannot survive until the end of the year. Therefore, a comprehensive step is needed in solving economic problems in Indonesia, especially in East Java.

Based on existing data, East Java is one of the centers of MSMEs in Indonesia. More than 13 million MSMEs are recorded in East Java and are one of the backbones of the East Java economy. The author highly recommends the East Java Provincial Government to schedule a special budget to help SMEs. The assistance in question is productive capital assistance as carried 
Impact of MSME Assistance Program by East Java Province to Resolve the Economic Impacts of Covid-19

Adriyanto, Maryanti, Pambudi

out by the central government by focusing on MSMEs that are not touched by the central government. If this step is taken, the authors believe that with the assistance provided by the East Java provincial government, MSMEs in East Java will be able to survive and have a greater effect by securing the existing contributions. Therefore, it is highly recommended that the Provincial Government immediately issue MSME assistance in East Java immediately, or at the maximum at the end of the year.

\section{REFERENCES}

Aldila, N. (2020). Dampak Covid-19, Jokowi: Pertumbuban Ekonomi Dunia Terkontraksi. Bisnis.Com. https://ekonomi.bisnis.com/read/20200926/9/1296899/dampak-covid-19-jokowipertumbuhan-ekonomi-dunia-terkontraksi-tajam

Alhaq, A. A. M. A. (2020). New Normal dan Hilangnya Kepercayaan Rakyat Pada Pemerintah. Lombok Post. https://lombokpost.jawapos.com/opini/03/06/2020/new-normal-dan-hilangnyakepercayaan-rakyat-pada-pemerintah/

Allam, Z. (2020). Surveying the Covid-19 Pandemic and its Implications (1st ed.). Elsevier. https://doi.org/10.1016/C2020-0-01743-3

Arfani, F., \& Nashrullah, H. (2020). Pemprov: 3,8 Juta Pekerja di Jatim Terdampak Sosial Ekonomi COVID-19. Antaranews.Com. https://www.antaranews.com/berita/1391722/pemprov38-juta-pekerja-di-jatim-terdampak-sosial-ekonomi-covid-19

Ashraf, B. N. (2020). Economic impact of government interventions during the COVID-19 pandemic: International evidence from financial markets. Journal of Behavioral and Experimental Finance, 27, 100371. https://doi.org/10.1016/j.jbef.2020.100371

Badan Pusat Statistik. (2019). Analisis Hasil Sensus Ekonomi Lanjutan Potensi Peningkatan Kinerja Usaha Mikro Kecil https://www.bps.go.id/publication/2019/03/05/66912048b475b142057f40be/analisishasil-se2016-lanjutan-potensi-peningkatan-kinerja-usaha-mikro-kecil.html

Badan Pusat Statistik. (2020). Hasil Survei Sosial Demografi Dampak COVID-19. https://www.bps.go.id/publication/2020/06/01/669cb2e8646787e52dd171c4/hasilsurvei-sosial-demografi-dampak-covid-19-2020.html

Bai, C., Quayson, M., \& Sarkis, J. (2021). COVID-19 pandemic digitization lessons for sustainable development of micro-and small- enterprises. Sustainable Production and Consumption, 27, 1989-2001. https://doi.org/10.1016/j.spc.2021.04.035

Booth, A., Sutton, A., Clowes, M., \& St.James, M. M. (2021). Systematic Approaches to a Successful Literature Review (1at ed.). SAGE Publications, Inc. https://uk.sagepub.com/en$\mathrm{gb} /$ eur/systematic-approaches-to-a-successful-literature-review/book270933

BPS Jawa Timur. (2020). Berita Resmi Statistik - Profil Kemiskinan di Jawa Timur Maret 2020. https://jatim.bps.go.id/pressrelease/2020/07/15/1136/persentase-penduduk-miskin-dijawa-timur-maret-2020-mencapai-11-09-persen-.html

Cahyadini, A., Dewi, S., Sugiharti, D. K., \& Muttaqin, Z. (2021). Direct Tax for Digital Platform During the COVID-19 Pandemic: Study in Indonesia. Journal of Southwest Jiaotong University, 56(2), 271-280. https://doi.org/10.35741/issn.0258-2724.56.2.22 
Impact of MSME Assistance Program by East Java Province to Resolve the Economic Impacts of Covid-19

Adriyanto, Maryanti, Pambudi

CNN Indonesia. (2020). Corona Buat 5.348 Pekerja Jatim Kena PHK, 32.365 Dirumabkan. CNN Indonesia. https://www.cnnindonesia.com/ekonomi/20200501211210-92-499335/coronabuat-5348-pekerja-jatim-kena-phk-32365-dirumahkan

Dewi, R. S. (2020). Evaluasi Penyaluran Bantuan Sosial (Bansos) Tahap Satu, Covid-19. Ombudsman Republik Indonesia. ttps://ombudsman.go.id/artikel/r/artikel--evaluasi-penyaluranbantuan-sosial-bansos-tahap-satu-covid-19-

Ihsanuddin. (2020, August 24). Jokowi Resmi Luncurkan Bantuan Produktif untuk Usaha Kecil. Kompas.Com. https://nasional.kompas.com/read/2020/08/24/14052941/jokowi-resmiluncurkan-bantuan-produktif-untuk-usaha-kecil

Jayani, D. H. (2020). Pemerintah Beri Stimulus, Berapa Jumlah UMKM di Indonesia. https://databoks.katadata.co.id/datapublish/2020/04/08/pemerintah-beri-stimulusberapa-jumlah-umkm-di-indonesia

Kustiningsih, W., \& Nurhadi. (2020). Penguatan Modal Sosial dalam Mitigasi COVID-19. UGM Press.

https://scholar.google.co.id/citations?view_op=view_citation\&hl=en\&user=13X_hy0AAA AJ\&citation_for_view=13X_hy0AAAAJ:kNdYIx-mwKoC

Mansoor, M. (2021). Citizens' trust in government as a function of good governance and government agency's provision of quality information on social media during COVID-19. Government Information Quarterly, 38(4), 101597. https://doi.org/10.1016/j.giq.2021.101597

Pemprov Jawa Timur. (2020). Jatim Tanggap Covid-19. Pemprov Jawa Timur. https://infocovid19.jatimprov.go.id/

Rahmah, N. A. (2020). The Impact of Covid-19 on Micro, Small, Medium Enterprises (UMKM) In Indonesia. Universitas Islam Negeri Antasari. https://www.academia.edu/42694142/Karya_Tulis_Ilmiah_Nadia_Amalia_Rahmah

Rowley, J., \& Slack, F. (2004). Conducting a literature review. Management Research News, 27(6), 31-39. https://doi.org/10.1108/01409170410784185

Santia, T. (2020, September). Berapa Jumlah UMKM di Indonesia? Ini Hitungannya. Liputan6.Com. https://www.liputan6.com/bisnis/read/4346352/berapa-jumlah-umkm-diindonesia-ini-hitungannya

Satuan Tugas Penanganan Covid-19. (2020). Peta Sebaran Pandemi Covid-19. https://covid19.go.id/peta-sebaran

Sekiraqa, A., Sekiraça, E., Sekiraqa, V., \& Ahmeti, S. (2021). The impact of COVID - 19 on Collecting of Tax Revenues in Kosovo. SHS Web of Conferences, 114, 01031. https://doi.org/10.1051/shsconf/202111401031

Shafi, M., Liu, J., \& Ren, W. (2020). Impact of COVID-19 pandemic on micro, small, and medium-sized Enterprises operating in Pakistan. Research in Globalization, 2, 100018. https://doi.org/10.1016/j.resglo.2020.100018

Sreeramula, S., \& Rahardjo, D. (2021). Estimating COVID-19 Rt in Real-time: An Indonesia health policy perspective. Machine Learning with Applications, 6, 100136. https://doi.org/10.1016/j.mlwa.2021.100136

Susanti, N., \& Widajatun, V. W. (2021). MSMEs Understanding of Taxation During the COVID-19 Pandemic. Journal of Innovation and Community Engagement, 2(1), 35-46. https://doi.org/10.28932/jice.v2i1.3689 
Impact of MSME Assistance Program by East Java Province to Resolve the Economic Impacts of Covid-19

Adriyanto, Maryanti, Pambudi

Tosepu, R., Gunawan, J., Effendy, D. S., Ahmad, L. O. A. I., Lestari, H., Bahar, H., \& Asfian, P. (2020). Correlation between weather and Covid-19 pandemic in Jakarta, Indonesia. Science of The Total Environment, 725, 138436. https://doi.org/10.1016/j.scitotenv.2020.138436

Utomo, C. D., \& Hanggraeni, D. (2021). The Impact of COVID-19 Pandemic on Stock Market Performance in Indonesia. The Journal of Asian Finance, Economics and Business, 8(5), 777-784. https://doi.org/https://doi.org/10.13106/jafeb.2021.vol8.no5.0777

Wanasida, A. S., Bernarto, I., Sudibjo, N., \& Pramono, R. (2021). Millennial Transformational Leadership on Organizational Performance in Indonesia Fishery Startup. Journal of Asian Finance, Economics and Business, 8(2), 555-562. https://doi.org/http://dx.doi.org/10.13106/jafeb.2021.vol8.no2.0555

Windarwati, H. D., Oktaviana, W., Mukarromah, I., Ati, N. A. L., Rizzal, A. F., \& Sulaksono, A. D. (2020). In the middle of the COVID-19 outbreak: Early practical guidelines for psychosocial aspects of COVID-19 in East Java, Indonesia. Psychiatry Research, 293, 113395. https://doi.org/10.1016/j.psychres.2020.113395

Yousef, I. (2020). Spillover of COVID-19: Impact on Stock Market Volatility. Journal of Psychosocial Rehabilitation, 24(6), 18069-18081. https://www.psychosocial.com/article/PR261476/34211/ 